\title{
LAND USE PLANNING FOR AGRO - FORESTRY PROGRAMMES \\ IN TEA ESTATES
}

\author{
J A A M Jayakody and R M M S Rajapaksa \\ Tea Research Institute, Talawakelle
}

Land use planning in tea estates is of prime importance in order to identify profitable and environmentally friendly land use options for lands unsuitable for tea. Agro-forestry is one of the land use options adopted in tea estates in order to meet the high fuel wood requirements of tea factories and estate labour communities. A study was undertaken to select lands for Agro-Forestry Programmes in five estates in the Nuwara Eliya district. Geographic Information System was used as a tool for land suitability classification. Uneconomical lands were classified based on factors such as existing tea type and present yield, geographical distribution within the estates, and slope and elevation. A range of lands were identified for immediate and future agro-forestry programmes. Potential improvement in profitability was estimated for individual estate and as a group of estates. 